\title{
EFFECT OF DIFFERENT FEEDING REGIMES ON: 2- PRODUCTIVE AND REPRODUCTIVE PERFORMANCE OF GROWING BUFFALO HEIFERS
}

\author{
Mona E. Farag'; M.A. Abd El-Latif ${ }^{2}$; S. A. Ebrahim ${ }^{2}$ and A. A Gabr ${ }^{2}$ \\ 1- Department of Animal Nutrition - Animal Production Research Institute \\ 2-Department of buffalo breeding - Animal Production Research Institute
}

(Received 10/3/2016, Accepted 10/5/2016)

\section{SUMMARY}

$\mathrm{T}$ This study was conducted to investigate the effect of different feeding levels on productive and reproductive performance and some body measurements of growing buffalo heifers during the period from first services up to ninetieth days of pregnancy. Eighteen buffalo heifers at the first services were divided into three treated groups ( 6 heifers each) and received their feeding allowance according to Kearl, (1982) in which animals in group one (R1) fed $100 \%$ of their allowances up to the end of the experiment (control) and those in group two (R2) fed $80 \%$ of the allowances until heifers grow up to 300 $\mathrm{kg}$, and then fed $100 \%$ of the allowances up to the end of the experiment, while those in the third group (R3) fed $80 \%$ of the allowances during the whole experimental period. Average age of heifers at first service was 517.3, 571.7 and 594.7 days old and live body weight were $347.8,339.3$ and $349.0 \mathrm{~kg}$ for R1, R2 and R3, respectively. Results indicated that heifers fed $80 \%$ of the allowance (R3) recorded the lowest values in most of nutrient digestion coefficients and feeding values (TDN and $\mathrm{CP} \%$ ) in comparison with the other experimental groups, while CF digestibility had the inverse trend. Also, animals in R3 recorded the lowest $(\mathrm{P}<0.05)$ blood constituents and oldest ages at first service and conception than those in other experimental groups. Heifers fed $100 \%$ of the allowance (R1) recorded the higher body condition score than those in the experimental groups. There were significant differences between heifers in both R1and R2 in comparison with those in R3 respecting the most of growth performance parameters and animals in both groups (R1 and R2) were significantly better than those in R2. However, Heifers fed $80 \%$ of the allowance (R3) had a better $(\mathrm{P}<0.05)$ feed conversion ratio expressed as the amount of intake of DM, TDN or CP than those in R1 and R2 groups. Interval from puberty to the first service or to conception was significantly shorter for heifers in R2 than those in R1 and R3 groups. Number of oestrous cycles from Puberty to the first service or to the conception was significantly the lowest with heifers in R1 followed by those in R2 then the highest values were recorded with those in R3 group. It could be concluded that feeding growing buffalo heifers at first service on (R2) had more beneficial effect on heifers' reproductive performance, indicating positive reflection on the subsequent first lactation season of primiparous cows under Egyptian condition.

Keywords: feeding levels, buffalo heifers, productive and reproductive performance.

\section{INTRODUCTION}

Increasing the human population all over the world requires continues supply of food from plant and animal sources. In Egypt there is massive gab between the human requirements of animal proteins and the national production of the whole animal products resources. Sill buffaloes breed rearing at very modest productive performance by smallholder in Egypt and most developing countries due to mostly the poor management factors especially malnutrition, marginal care of heath and reproduction as well as the harsh condition of environment. There are several constraints to increase production from smallholder systems, including quality and quantity of livestock feeds, livestock diseases, adverse climate, unfavorable agricultural policies, poor infrastructure and low productivity of livestock. Reproduction is a vital factor 


\section{Farag et al.}

in determining the efficiency of animal production. The relationship between nutrition and reproduction in ruminants is complex and often quite variable.

Feeds are the most important cost item for livestock production representing about $70 \%$ of the total production costs (Abdel-Salam, 2003). Feeding level is the limited factor affecting average daily gain, age at puberty, first service and conception in buffalo heifers (Shahin, 2004 and Shahin et al., 2012) and Baladi heifers (El-Banna, et al.,2004).

Nutrients supply are a component of the management system that carefully be under the control of the farmer and continuously being monitoring to be in convenience with different stages of animal (Boland, 2002). Nutritional components especially energy and protein level (feeding levels) and requirement allowances are the most important factor affecting the physiological and metabolic status, growth rate at different ages and productive stages, weight at puberty and onset of first service, good body measurements and body condition insures maximum production and high reproduction efficiency and lifetime production of the buffalo heifers (Deutscher et al., 1986 and Shahin et al., 2004).

The main limiting factor for the milk yield potential of cows is the number of milk synthesizing cells in the mammary glands (Knight and Wilde, 1994). For the overall economy of the dairy industry, it is also important to minimize the costs of raising replacement heifers. The most effective way to reduce rearing costs is to lower the age at first calving. Therefore, heifers need to be raised on a high growth rate feeding regimen until puberty to obtain a substantial reduction of age at first calving. However, high growth rates before puberty can impair mammary development and future milk production. Thus, to develop the optimum feeding and management regimen for heifers, it is necessary to understand the multi-relationship among onset of puberty, pubertal mammary development, and feeding level and to know the possible consequences for the milk yield potential. The main source of within-breed variation in age at onset of puberty is level of feeding (see reviews by Moran et al., 1989; Robinson, 1990; Schillo et al., 1992). In supporting to these findings, Mantysaari et al., 1995 and Sejrsen et al., 1998 shown that an excessive feeding before puberty can impair mammary development and decease subsequent milk yield as reported by (Peri et al., 1993 and Radcliff et al., 2000). On applied experiment, Borghese et al., (1997) found that buffalo heifers reared on pasture system (unexcessive feeding) promoted the best performance in heifers, because of the economy of feeding with favorable daily gain and early age at puberty and at conceiving. They were added that heifers on pasture showed profitable body gain ( $718 \mathrm{~g} /$ day), age at puberty (569 days) and weight at puberty ( $378 \mathrm{~kg}$ ) vs. the corresponding values on corn silage feeding system were 684 g/day, 603 days and $426 \mathrm{~kg}$. On the other hand, stair-step feeding (high feeding intensity following lower) of pregnant heifers has been reported to increase milk yield postpartum (Choi et al., 1997). Furthermore, stair-step feeding increased the differentiation and functional activity of the mammary glands. Collectively, Mantysaari et al., (1999) found that feeding intensity 2 to 6 months of gestation had no effect on milk production ability of primiparous cows, but a high feeding intensity during the last trimester (7-9 months of pregnancy) increased milk yield.

The present study aims to assess the possibility of applying the effect feeding level on productive and reproductive performance of growing buffalo heifers raised.

\section{MATERIALS AND METHODS}

\section{Treatments and management}

This study was conducted at El-Gemmiza Agricultural Research Station, Animal Production Research Institute, Agriculture Research Center, Ministry of Agriculture, Egypt.

Eighteen growing buffalo heifers averaged $156 \pm \ldots$ days and $110 \pm \ldots . \mathrm{kg}$ live body weight were allotted randomly into three treated groups of six each. The first part of experiment is published (Shahin et al., 2016), while the second part (the current work) was started at the first service with a live body weight of $347.8,339.3$ and $349.0 \mathrm{~kg}$ and age of $517.3,571.7$ and 594.7 days for animals in groups one (control, R1), two (R2) and three (R3), respectively. A comparative feeding trial using the randomized complete block design in which animals in the control group (R1) was fed on $100 \%$ of the allowances during the whole experimental period. Animals in R2 was fed on $80 \%$ of the allowances till heifers reached $300 \mathrm{~kg}$ live body weight and then received $100 \%$ of the allowances till the end of the experiment, while those in R3 was fed on $80 \%$ of the allowances during the whole experimental period. 
All nutritional allowance of all groups were calculated according to Kearl, (1982) and the experiment was ended when the heifers reached the first 90 days from pregnancy. All heifer groups were fed on ration formulated from $50 \%$ concentrate and 50\% roughage. The offered roughage was consisted of $30 \%$ corn silage, $10 \%$ berseem hay $(\mathrm{BH})$ and $10 \%$ rice straw (RS). The ration was formulated to meet the nutritional allowance of heifers during the hormonal development period, growth compensatory during the period of service and the stability of pregnancy until the first 90 days of pregnancy. The concentrate feed mixture (CFM) was offered twice daily before check for oestrous at 7 am and $4 \mathrm{pm}$, while roughage was offered at 8 am and $5 \mathrm{pm}$. Minerals blocks and fresh water were available all the day time. During the experiment, individual feed intake was daily recorded, while live body weight was biweekly determined before the morning feeding and feed allowance was adjusted accordingly. All heifers were kept under semi-open sheds and individually feeding system was applied. Mammary development of heifers was measured twice monthly according to sejrsen and purup (1997). Heifers were examined clinically and for the pattern of embryonic loss from days 28 to 84 of gestation. The body weight of heifers was adjusted all days just before calving (before expectation of calving).

\section{Sampling and analysis}

Daily intake of CFM, corn silage, BH and RS was recorded throughout the experiment period. Representative samples of offers ingredients, refusals and feces were analyzed according to the A.O.A.C. (1995). Chemical analysis of different feedstuffs and calculated composition of the experimental rations are presented in Table (1).

Blood samples were taken monthly from all the experimental heifers at three hours after morning feeding and left at room temperature for 45-60 minutes, then centrifuged at 4000 r.p.m for 15 minutes. Blood serum was separated and stored at $-20^{\circ} \mathrm{C}$ until later analyses. Blood samples were analyzed for total protein (Henry, 1964), albumin (Doumaset al., 1971) and urea (Patton and Crouch, 1977), while globulin was calculated by subtraction of serum albumin from total serum protein. Glucose and cholesterol were quantified in blood serum by using kits of Spinreact, S.A.U. Ctra. Santa Coloma, 7 E17176 SantEsteve de Bas (GI), Spain by means of spectrophotometer. Direct RIA technique was performed for assessment of total serum tri-iodothyronine (T3) and thyroxine (T4) concentrations by Kits according to the procedure outlined by the manufacturer.

The digestibility trial was conducted on all heifers at the end of feeding trial. Fecal grape samples were taken from heifers at three successive days and composted for each animal to determine total apparent digestibility using silica (McDonald et al., 1995) as an internal marker. The data were analyzed according to statistical analysis system, (SAS) User's Guide, (1998). Differences among means was carried out by using Duncan multiple range test (Duncan, 1955).

Table (1): Chemical composition of the different feedstuffs and calculated chemical composition of experimental rations.

\begin{tabular}{lcccccc}
\hline Item & DM & CP & EE & CF & NFE & Ash \\
\hline CFM & 88.76 & 15.87 & 2.39 & 14.12 & 61.41 & 6.21 \\
Corn silage & 37.59 & 7.20 & 1.87 & 25.11 & 50.99 & 14.83 \\
Berssem hay & 88.63 & 13.52 & 0.54 & 27.93 & 45.73 & 12.28 \\
Rice Straw & $89 . .01$ & 2.94 & 1.12 & 39.21 & 39.47 & 17.26 \\
*Ration (TMR) & 73.42 & 11.74 & 1.92 & 21.31 & 54.52 & 10.51 \\
\hline
\end{tabular}

TMR : Total mixed rations consists of 50:50 concentrate: roughage ratio and roughage consisted of $30 \%$ corn silage, $10 \%$ berseem hay and $10 \%$ rice straw.

\section{RESULTS AND DISCUSSION}

\section{Nutrients Digestibility}

Data in Table (2) showed that animals fed R1 and R2 recorded higher $(\mathrm{P}<0.05)$ digestibility of $\mathrm{DM}$, $\mathrm{CP}, \mathrm{EE}$ and NFE, in addition to a higher feeding value (DCP and TDN\%) than those fed R3, while the difference between those in R1 and R2 was not significant. On the contrary the highest $(\mathrm{P}<0.01)$ digestion coefficient of $\mathrm{CF}$ was recorded for animals fed $\mathrm{R} 3$ ration than those fed R1 and R2. The highest digestion coefficients of CF in R3 may be due to the fact that decreasing DM intake could increase feed retention in 


\section{Farag et al.}

the rumen, which in turn led to an improvement in digestibility. Many investigators reported similar findings (Ahamed et al., 2003; Shahin et al., 2004; Shahin, 2007; Shahin et al., 2016) in which as increasing the feeding level, digestibility of all nutrients were markedly increased with the exception of CF digestibility. On contrary, Steingass et al. (1994) found that the nutrient digestibility decreased linearly with the increase of feeding level. When animals in R2 received $100 \%$ of their requirements during the second period, this led to an improvement in digestibility and feeding values than those in R3 which would be reflected on productive and reproductive performance in the future.

Table (2): Effect of feed intake level and dietary treatment on nutrients digestibility with growing replacement buffalo heifers.

\begin{tabular}{lcccc}
\hline & $\mathrm{R} 1$ & $\mathrm{R} 2$ & $\mathrm{R} 3$ & $\mathrm{SE}$ \\
& $100 \%$ & $80 / 100 \%$ & $80 \%$ & \\
\hline Feed intake, kg/head/day & & & & \\
DM & 9.5 & 9.5 & 7.60 & \\
TDN & 5.57 & 5.57 & 4.45 & \\
CP & 1.12 & 1.12 & 0.89 & \\
Digestibility, \% & & & \\
DM & 71.11 & 69.25 & 68.34 & 0.27 \\
CP & $67.76^{\mathrm{a}}$ & $66.59^{\mathrm{a}}$ & $63.71^{\mathrm{b}}$ & 0.26 \\
CF & $52.72^{\mathrm{b}}$ & $53.47^{\mathrm{b}}$ & $58.11^{\mathrm{a}}$ & 1.21 \\
EE & $74.26^{\mathrm{a}}$ & $73.88^{\mathrm{a}}$ & $68.55^{\mathrm{b}}$ & 0.41 \\
NFE & 76.22 & 76.46 & 73.42 & 0.24 \\
Feeding values & & & & \\
TDN & 64.99 & 64.15 & 62.87 & 1.33 \\
DCP & $7.96^{\mathrm{a}}$ & $7.88^{\mathrm{a}}$ & $7.50^{\mathrm{b}}$ & 0.22 \\
\hline band $:$ Means in the same row with different superscripts are significant $(P<0.05)$ & &
\end{tabular}

$-a, b$ and $c:$ Means in the same row with different superscripts are significant $(P<0.05)$.

\section{Blood serum parameters:}

The results of blood parameters are shown in Table (3). The heifers in R3 recorded the lowest $(\mathrm{P}<0.05)$ concentration of glucose, total protein, albumin, globulin and urea than those of the other treated groups. These results are in agreement with the findings of Ali et al. (2014) and Shahin (2016) who revealed that serum glucose was significantly increased in growing heifers fed high vs. low energy diets. Also, El-Ashry et al. (2007 and 2008) concluded that concentrations of total protein, albumin, globulin and urea increased with increasing feeding level (energy and protein). Similar results were obtained by Abu El-Hamd et al. (2006) who found that the concentration of total protein and its derivatives was increased in blood of growing buffalo heifers after supplemented their ration by certain amounts of protein supplement and corn silage.

These results may be due to a higher digestibility and a higher feeding value which expressed as DCP (Table 2). These findings confirmed the concept of Mosaad and Derar (2009) who reported that energy and protein metabolism are closely intertwined in ruminants. This complex balanced system is further complicated as most of the carbohydrates consumed by ruminants are fermented in the rumen to VFAs and limited glucose is available to absorption. Therefore, glucogenesis is of great importance to ruminants. Propionate is the major source of glucose (27-55\%), and glucogenic amino acids supplies a significant amount (15-36\%) of the glucogenic materials. The present values of serum total protein and urea concentration are within the normal values of ruminants (between 6.45 to $8.01 \mathrm{~g} / \mathrm{dl}$. and 41.88 to $53.01 \mathrm{mg} / \mathrm{dI}$, respectively). These results are in contrast with the findings of Ibrahim et al. (2005) who found that serum albumin was insignificantly lower in Baladi calves and their crosses with Abondance and Tarentaise fed high levels of TDN and DCP compared to those fed low ones. Results concerning the cholesterol concentration with heifers fed different levels of TDN and DCP are presented in Table (3). 
Blood cholesterol concentration ranged from 64.61 to $70.41 \mathrm{mg} / \mathrm{dl}$. Also the results showed that the concentrations of cholesterol of heifers fed high feeding level were significantly increased in comparison with those fed low feeding level. These results are in harmony with those reported by Schrick et al. (1990) who found that cows fed high energy levels had higher concentrations of serum cholesterol. The mean values of T3 and T4 in blood serum of heifers fed different feeding levels are shown in Table (3). Concerning the values of T3 and T4 concentrations, it could be noticed that heifers fed high feeding level were significantly $(\mathrm{P}<0.05)$ higher than those fed low one. Values of $\mathrm{T} 3$ and $\mathrm{T} 4$ are proportionally correlated with the levels of feeding. These findings may reflect a good feed utilization, absorption and metabolism for heifers fed high feeding levels than those of low ones. Thyroid hormones (T3 and T4) synergize with other hormones to promote growth and development of the mammary gland and maintenance of lactation.

Table (3): Some blood serum constituents of growing buffalo heifers fed the experimental rations.

\begin{tabular}{lcccc}
\hline & \multicolumn{3}{c}{ First period } \\
\cline { 2 - 5 } & $\mathrm{R} 1$ & $\mathrm{R} 2$ & $\mathrm{R} 3$ & $\mathrm{SE}$ \\
\hline Glucose, mg/dI & $81.69^{\mathrm{a}}$ & $80.76^{\mathrm{a}}$ & $69.39^{\mathrm{b}}$ & 2.20 \\
Total protein, g/dI & $8.13^{\mathrm{a}}$ & $8.07^{\mathrm{a}}$ & $6.78^{\mathrm{b}}$ & 0.14 \\
Albumin, g/dI & $4.32^{\mathrm{a}}$ & $4.17^{\mathrm{a}}$ & $3.42^{\mathrm{b}}$ & 0.30 \\
Globulin, g/dI & $3.81^{\mathrm{a}}$ & $3.9^{\mathrm{a}}$ & $3.36^{\mathrm{b}}$ & 0.31 \\
Urea, mg/dI & $52.24^{\mathrm{a}}$ & $51.77^{\mathrm{a}}$ & $44.24^{\mathrm{b}}$ & 4.65 \\
Cholesterol, mg/dI & $70.41^{\mathrm{a}}$ & $69.34^{\mathrm{a}}$ & $64.61^{\mathrm{b}}$ & 4.11 \\
T3, nmol/L & $1.36^{\mathrm{a}}$ & $1.38^{\mathrm{a}}$ & $1.16^{\mathrm{b}}$ & 0.17 \\
T4, nmol/L & $70.79^{\mathrm{a}}$ & $71.11^{\mathrm{b}}$ & $65.84^{\mathrm{b}}$ & 2.11 \\
\hline
\end{tabular}

$-a, b$ and $c$ : Means in the same row with different superscripts are significant $(P<0.05)$.

Greater nutrient intake increased concentrations of thyroid hormones (Delavaud et al., 2002) and these hormones were positively correlated with the most vital metabolic processes and subsequently reproductive performance of animals. Earlier Apgar et al. (1975) demonstrated that various dietary insufficiencies might affect any of the three organs (hypothalamus, pituitary or ovary), depending on which nutrient is limited. A high energy diet fed chronically to heifers was associated compared with heifers fed low energy diet (Imakawa et al., 1983). Furthermore, El-Banna et al. (2004) indicated that energy and protein intake offered during pre- and post-pubertal period have an effective role on growth and ovarian activity in Baladi heifers.

\section{Body measurements}

The results of some body measurements of heifers feeding different experimental rations are presented in Table (4). In the current work we were planning to discusse the body measurements from the beginning of the first part (Shahin et al., 2016) until the end of second part (at first 90 days from pregnancy).

Under the conditions of the current study, data showed no significant differences among treated goups regarding all tested body measurements at the end of the experimental period except for body condition score in which heifers fed $\mathrm{R} 1$ recorded a highest $(\mathrm{P}<0.05)$ values followed by $\mathrm{R} 2$ and then $\mathrm{R} 3$ was ranked the last. This might be attributed to the higher fed intake for animals in R1 compared to those in other treated groups. These results are in agreement with those reported by Olsson et al. (1997), Shahin (2000) and Etman et al. (2007).

The results also indicated that heifers fed high level of feeding had significantly greater values of total heart girth measurement $(\mathrm{P}<0.05)$ as compared with other treatments. No significant differences were found in total gain between heifers on different feeding treatments for either rumen girth and Width at hips. However, width at withers, heifers received R2 recorded significant higher values of total and daily gain than those of R1 and no significantly differed than those of R3. Previous findings revealed some agreement with regard to nutritional effects on ovine skeletal dimensions. In this respect, D'-Hour et al. (1996) and Etman, et al. (2007) reported the improvement of some body measurements of heifers by increasing dietary feeding level. Definitely, replacement dairy heifers skeletal growth is important. It is usually measured by heart girth, wither height, body length, hip width and hip height. Heinrichs and Hargrove (1994) have assessed the optimal body size criteria for replacement heifers. Wither height of cow is considered to be important because tall animals have longer bodies and therefore more body capacity. Tall cows also have udders higher off the ground which is important for injury prevention and ease of milking. In addition, in the study of Heinrichs and Hargrove (1987), there was a positive 


\section{Farag et al.}

correlation between average herd milk production and estimated mean heifer wither height at 24 months of age. Mantysaari (2001) found that wither height was higher $(\mathrm{P}<0.01)$ for those fed low compared to high feeding level at $220 \mathrm{~kg}$ live weight (L.W). Furthermore, Stelwagen and Grieve (1990) and Radcliff et al. (2000) observed higher wither height at puberty (290 kg L.W) and at breeding for heifers fed on low compared to high feeding levels. Thus, it seems that at the same L.W restrictively fed heifers are taller than intensively reared heifers.

Table (4): Some body measurements and body condition score of growing buffalo heifers fed different experimental rations.

\begin{tabular}{|c|c|c|c|}
\hline \multirow[t]{2}{*}{ Item } & \multicolumn{3}{|c|}{ Rations } \\
\hline & R1 & $\mathrm{R} 2$ & R3 \\
\hline \multicolumn{4}{|c|}{ Body measurements, $\mathrm{cm}$} \\
\hline \multicolumn{4}{|l|}{ Heart girth } \\
\hline Initial & $137.0 \pm 6.56$ & $135.7 \pm 9.50$ & $140.3 \pm 10.59$ \\
\hline Final & $176.8 \pm 15.13$ & $174.5 \pm 11.76$ & $176.5 \pm 18.50$ \\
\hline Total gain & $39.76^{\mathrm{a}}$ & $38.78^{\mathrm{a}}$ & $36.15^{\mathrm{b}}$ \\
\hline \multicolumn{4}{|c|}{ Rumen girth } \\
\hline Initial & $147.7 \pm 7.51$ & $149.3 \pm 9.71$ & $147.4 \pm 7.64$ \\
\hline Final & $239.8 \pm 15.31$ & $242.9 \pm 19.05$ & $244.0 \pm 22.94$ \\
\hline Total gain & 92.15 & 93.59 & 96.59 \\
\hline \multicolumn{4}{|c|}{ Width at withers } \\
\hline Initial & $14.5 \pm 1.15$ & $14.3 \pm 0.58$ & $14.1 \pm 0.67$ \\
\hline Final & $27.1 \pm 1.53$ & $27.8 \pm 1.15$ & $26.6 \pm 1.73$ \\
\hline Total gain & $12.54^{\mathrm{b}}$ & $13.44^{\mathrm{a}}$ & $12.95^{\mathrm{ab}}$ \\
\hline \multicolumn{4}{|c|}{ Width at hips } \\
\hline Initial & $29.3 \pm 1.53$ & $28.3 \pm 1.89$ & $29.0 \pm 2.11$ \\
\hline Final & $52.7 \pm 1.01$ & $52.6 \pm 2.08$ & $52.8 \pm 2.24$ \\
\hline Total gain & 23.39 & 24.30 & 23.74 \\
\hline \multicolumn{4}{|c|}{ Body condition score } \\
\hline Initial & $1.5 \pm 0.22$ & $1.4 \pm 0.27$ & $1.5 \pm 0.29$ \\
\hline Final & $3.3^{\mathrm{a}} \pm 0.60$ & $2.9^{\mathrm{b}} \pm 0.32$ & $2.6^{\mathrm{c}} \pm 0.35$ \\
\hline Total gain & $1.80^{\mathrm{a}}$ & $1.41^{\mathrm{b}}$ & $1.18^{\mathrm{c}}$ \\
\hline
\end{tabular}

$a, b$ and $c:$ Means in the same row with different superscripts are significant $(P<0.05)$.

\section{Growth performance:}

Results of growth performance of heifers are presented in Table (5). Data showed that weight at first service, conception and first 90 days from pregnancy were almost similar among treated groups. However, animals received $80 \%$ feeding level (R3) appeared to show lower total and daily gain at first service to conception and from conception to first 90 days from pregnancy than those in the other treatments. Similarly, daily gain of heifers over both growing stages was behaved at the same trend of the total gain among dietary treatments. This might be attributed to the differences in feeding level systems, digestibility coefficients and feeding values during this period and this was associated with large difference in age of heifers at puberty. These results are in agreement with those achieved by El-Ashry et al. (2008), Etman et al. (2007), Ali et al. (2014) and Shahin et al. (2016) who reported that heifers offered high energy and protein levels (feeding level) had significantly higher total body weight gain and daily gain than those fed low energy and protein levels. On the other hand, Almquist and Amann (1976) reported that weight and age at different reproductive performance stage could be considered a genetic character. It is worthy to note that growth performance (total and daily gain) in particularly from conception to the first 90 days of pregnancy was approximately similar between heifers fed $100 \%$ of their requirements (R1) and those fed $80 \%$ followed by $100 \%$ of the feeding allowances (R2) and this result greatly due to the phenomenon of compensatory growth. Mantysaari (2001) noticed that marked compensatory growth during the last trimester of gestation with growing heifers. They added that heifers fed on moderate plan of nutrition during the first two trimesters of gestation and then moved to higher level during the last trimester grew significantly faster during the lost trimester than the heifers who had received high feeding level throughout the whole gestation period. In support to these results, Choi et al. (1997) reported that stair-step feeding (high feeding intensity following lower) of pregnant heifers has been increased milk yield postpartum. Furthermore, stair-step feeding increased the differentiation and 
functional activity of the mammary gland. A possible explanation for enhanced mammary differentiation and milk production measured in the compensatory growth pattern associated with stair-step rearing are the changes in hormone secretion and enzymatic activities (Park et al., 1988 and 1989).

Data presented in Table (5) showed that the feed conversion were determined at different stages of growth of heifers. Heifers fed R3 ration had a better $(\mathrm{P}<0.05)$ feed conversion ratio expressed as the amount of intake of DM, TDN or CP to give one $\mathrm{kg}$ gain compared to the other treatments. This might be attributed to the heifers received $80 \%$ feeding level (R3) that appeared to show significant lower in DM, TDN and CP intake compared to the other treatments. This is due to the differences in feeding level systems, daily gain, digestibility coefficients and feeding values during this period. These results are in harmony with those obtained by Shahin (2004), El-Ashry et al. (2008), Etman et al. (2007) and Shahin et al. (2016).

Table (5): Growth performance of growing buffalo heifers fed different experimental rations.

\begin{tabular}{lccc}
\hline Item & \multicolumn{3}{c}{ Rations } \\
\cline { 2 - 4 } & $\mathrm{R} 1$ & $\mathrm{R} 2$ & $\mathrm{R} 3$ \\
\hline Weight changes, $\mathrm{kg}$ & & & $349.0 \pm 12.86$ \\
at first service & $347.83 \pm 10.25$ & $339.33 \pm 13.41$ & $352.36 \pm 14.11$ \\
at conception & $355.71 \pm 12.36$ & $345.67 \pm 11.89$ & $399.91 \pm 21.52$ \\
at first 90 days from pregnancy & $407.96 \pm 18.50$ & $398.37 \pm 17.56$ & $3.36^{\mathrm{c}}$ \\
Total gain, kg & & & $47.55^{\mathrm{b}}$ \\
first service to conception & $7.94^{\mathrm{a}}$ & $52.74^{\mathrm{b}}$ & \\
first 90 days from pregnancy & $52.19^{\mathrm{a}}$ & & $0.384^{\mathrm{b}} \pm 0.023$ \\
Daily gain, kg & & $0.454^{\mathrm{a}} \pm 0.028$ & \\
first service to conception & $0.474^{\mathrm{a}} \pm 0.041$ & $0.586^{\mathrm{a}} \pm 0.035$ & $13.06^{\mathrm{b}}$ \\
first 90 days from pregnancy & $0.580^{\mathrm{a}} \pm 0.052$ & & $7.66^{\mathrm{b}}$ \\
Feed conversion: & & $15.19^{\mathrm{a}}$ & $1.53^{\mathrm{b}}$ \\
$\mathrm{kg}$ DM / kg gain & $15.34^{\mathrm{a}}$ & $8.9^{\mathrm{a}}$ & $1.78^{\mathrm{a}}$ \\
kg TDN / kg gain & $8.99^{\mathrm{a}}$ & $1.80^{\mathrm{a}}$ &
\end{tabular}

Generally, results in Table (5) showed that heifers received $80 \%$ of their allowances till reached 300 $\mathrm{kg}$ live weight and then $100 \%$ of allowances till the end of the experiment (R2) had affected positively $(\mathrm{P}<0.05)$ the total body weight gain and daily gain at both stages of growth compared to those received $80 \%$ of their allowances during the whole experimental period (R3). Consistent with the results here, Grummar et al. (1995) demonstrated that a high plane of nutrition during gestation has often failed to increase milk production of primiparous cows. The degree and duration of high feeding level and also the plane of nutrition before gestation are likely to be important for these results. Additionally, Foldager and Sejsen (1991) reported an increase in mammary development and milk production when prepartum (325 $\mathrm{kg} \mathrm{BW}$ to calving) daily gain increased from 400 to $600 \mathrm{~g}$ daily. A further increase in daily gain (800 g/ day) did not improve milk production. In other studies, a high feeding intensity during the last 6, 12 or 24 weeks before calving had no effect on milk yield (Foldager and Ingvartsen, 1995). A high feeding intensity for 24 weeks was, however, associated with decreased postpartum feed intake which is in accordance with Grummar et al. (1995) who found a negative effect of high prepartum feeding intensity on dry matter intake with no change in milk production.

\section{Reproductive performance:}

Data regarding the age of heifers at puberty, first service and conception are presented in Table (6). The age at puberty, first service, conception and first 90 days from pregnancy were 428.5, 504.5 and 504.7 days and 517.3, 571.7 and 594.7 days and 550.8, 602.2 and 624.1 days and 640.8, 692.2 and 714.1 days, respectively. Heifers fed control rations (R1) attained earlier at puberty, first service and conception compared to the other experimental treatments, while heifers fed R3 ration significantly showed the oldest ages, with insignificantly differences with respecting the three measured ages. These findings indicated pronounced effect of reducing rather than increasing feeding level (Table 5) on age at first service and then at conception. These findings agreed well with those obtained by Whitaker et al. (1993), Hall et al. (1994), Prasad et al. (1995) and Shahin (2007) who concluded that heifers and different female animals fed on low feeding level were significantly older at $1^{\text {st }}$ service than those on the high feeding level. 
Farag et al.

Table (6): Reproductive performance of growing buffalo heifers fed different experimental rations.

\begin{tabular}{lccc}
\hline Item & \multicolumn{3}{c}{ Rations } \\
\cline { 2 - 3 } & $\mathrm{R} 1$ & $\mathrm{R} 2$ & $\mathrm{R} 3$ \\
\hline Age of heifers, day & & & \\
at puberty & $428.50^{\mathrm{b}} \pm 22.81$ & $504.49^{\mathrm{a}} \pm 24.22$ & $504.74^{\mathrm{a}} \pm 21.82$ \\
at first service & $517.25^{\mathrm{b}} \pm 26.22$ & $571.69^{\mathrm{a}} \pm 36.81$ & $594.66^{\mathrm{a}} \pm 25.77$ \\
at conception & $550.75^{\mathrm{b}} \pm 25.55$ & $602.19^{\mathrm{a}} \pm 35.24$ & $624.06^{\mathrm{a}} \pm 25.44$ \\
Interval (day) from: & & & $89.92^{\mathrm{a}}$ \\
Puberty to first service & $88.75^{\mathrm{a}}$ & $67.20^{\mathrm{b}}$ & $98.68^{\mathrm{b}}$ \\
Puberty to conception & $105.5^{\mathrm{a}}$ & $81.18^{\mathrm{c}}$ & \\
Number of oestrous cycles from: & & & $4.56^{\mathrm{a}}$ \\
Puberty to first service & $2.25^{\mathrm{c}}$ & $3.49^{\mathrm{b}}$ & $6.31^{\mathrm{a}}$ \\
Puberty to conception & $3.92^{\mathrm{c}}$ & $5.49^{\mathrm{b}}$ & $22.10^{\mathrm{a}}$ \\
\hline
\end{tabular}

$a, b$ and $c:$ Means in the same row with different superscripts are significant $(P<0.05)$.

Interval from puberty to the first service or to conception was significantly $(\mathrm{P}<0.05)$ shorter for heifers received R2 than those in other treated groups which showed the longest interval. The present results are nearly similar to those obtained by Whitaker et al. (1993), Hall et al. (1994), Prasad et al. (1995) and Shahin (2007). In this respect, Niekerk et al. (1990) and Freetly and Cundiff (1998) reported that the level of feeding of heifers up to mating at 2 years has little effect on their reproductive performance. In support to the previous findings, Borghese et al. (1996) found that buffalo heifers fed high level (5.56 MFU/d) had a daily gain of $562 \mathrm{~g}$ versus $465 \mathrm{~g}$ of those fed low level (4.42 MFU/d), and reached puberty 30 days earlier. They also reported that it is possible to rear heifers on pasture with obtaining the same performances of those reared through the intensive feeding on condition that the daily gain is nearly 600 $\mathrm{g}$ /day. Heifers on pasture realized their reproductive performance with less energy consumption, the best feed efficiency and the lowest cost in term of feeding stuff and management. Also, El-Ashry (1992) reported that the buffalo heifers fed to cover daily gain of about $450 \mathrm{~g}$ (control) in comparison with other two group fed on 120 and $135 \%$ of the control ration showed that the age at first service were $22.8,22.8$ and 23.1 months, respectively. The corresponding live weights were 337.9, 356.5 and $358.6 \mathrm{~kg}$. Also, age (month) and body weights (kg) at fertile services were 24.9 and 364.9; 24.0 and 364.9 and 23.9 and 367.7, respectively, indicating no significant differences neither in age nor in body weight of the different treated groups.

\section{Oestrous activity}

Number of oestrous cycles from puberty to first service or to conception were significantly $(\mathrm{P}<0.05)$ the lowest with heifers fed R1, followed by R2, while the heifers fed R3 recorded the highest values. This might be attributed to the different feeding lines, which led to different interval from puberty to the first service or to conception. On the other hand, average oestrous cycle length was affected significantly by feeding levels, being longer in those fed R3, followed by those in R2, while heifers at control (R1) recorded the shortest ones, with insignificant differences between those in R2 and R3. These findings are nearly similar to those obtained by Whitaker et al. (1993), Hall et al. (1994), Prasad et al. (1995) and Shahin (2007) who reported that heifers receiving low feeding level had a significantly longer postpartum interval to oestrous than heifers given the high feeding level. In this respect, Niekerk et al. (1990) and Freetly and Cundiff (1998) reported that the feeding level of heifers up to mating at 2 years has a little effect on their reproductive performance. In general, several factors such as climate, temperature, photoperiod, nutrition have been shown to affect the length of oestrous cycle and the degree of heat expression.

\section{Conception and pregnancy rates:}


Data of conception rate (CR\%), number of service per conception (NS/C) and pregnancy rate (PR) of buffalo heifers as affected by dietary feeding levels are shown in Table (7). Results indicated that CR of the $1^{\text {st }}$ and $2^{\text {nd }}$ service was almost higher for the heifers fed R2 than those in the other treated groups. All heifers at different feeding groups were conceived (R1, R2 and R3) after the $3^{\text {rd }}$ service. However, the (NS/C) after the $2^{\text {nd }}$ service was the highest for heifers in R1 group followed by those in R2 group (1.5) and then those in R3 group had the lowest number. On the other hand, the (NS/C) after the $2^{\text {nd }}$ and $3^{\text {rd }}$. service was the highest for those in R1 compared to the other treated groups, while those in R3 recorded the lowest values. Results indicated that heifers in R2 and R3 had more beneficial effect regarding the reproductive performance compared to the other groups. These may be due to the faster development of sex organs with advancing age (El-Feel et al., 1992). On the other hand, the different plan of feeding was maintained throughout the rearing period with regarding to the different phases of mammary development. It has been found that there is a relationship between the different feeding level, average daily gain, age at puberty, first service and conception and the rate of mammary growth. Sejrsen et al. (1983) and (1998) observed that mammary development was incomplete in cow raised on high feeding level. Furthermore, the glands of cows raised on high feeding level were clearly different in shape and size from glands of those raised on moderate feeding level (Foldager and Sejrsen, 1991). This may be due to the role of the GH-IGF-1 axis because GH is required for mammary development and on the same time is affected by feeding level. Circulating levels of GH are reduced by high feeding level and blood GH is positively correlated with mammary growth (Sejrsen et al., 1983 and 2000) and exogenous administration of GH enhances puberty mammary growth (Sejrsen et al., 1986 and Purup et al., 1983). Most studies have also shown that the pre-pubertal period is central for nutritional manipulations of mammary growth.

Data of pregnancy rate are shown in table (7). The pregnancy rate on the basis of number of conceived or total animals in each experimental group was similar in all treated groups. The heifers were examined clinically and pattern of embryonic loss from days 28 to 84 of gestation. Results showed that the embryonic loss (mortality) was not found for heifers fed different plan of nutrition. Many investigators reported similar findings (Diskin et al., 2000, Silke et al., 2002 and Shahin et al., 2012).

\section{CONCLUSION}

It could be concluded that feeding growing buffalo heifers at $80 \%$ of the feeding allowances according to Kearl (1982) till $300 \mathrm{~kg}$ live weight and then fed $100 \%$ of the allowances to the first 90 days of pregnancy was more suitable for productive and reproductive performance.

Table (7): Oestrous and mating performance of growing buffalo heifers fed different experimental rations.

\begin{tabular}{|c|c|c|c|}
\hline \multirow[t]{2}{*}{ Item } & \multicolumn{3}{|c|}{ Rations } \\
\hline & R1 & $\mathrm{R} 2$ & R3 \\
\hline \multicolumn{4}{|l|}{ No. of conceived heifers after: } \\
\hline $1^{\mathrm{ST}}$ service & 3 & 4 & 5 \\
\hline $2^{\text {rd }}$ service & 2 & 2 & - \\
\hline $3^{\text {Srd }}$ service & 1 & - & 1 \\
\hline $\mathrm{Ns} / \mathrm{C}$ after the $2^{\text {nd }}$ service & 1.8 & 1.5 & 1.4 \\
\hline $\mathrm{Ns} / \mathrm{C}$ after the $3^{\text {rd }}$ service & 1.67 & - & 1.33 \\
\hline \multicolumn{4}{|l|}{ Cumulative conception rate $\%$ after: } \\
\hline $1^{\mathrm{ST}}$ service & 50 & 50 & 83.33 \\
\hline $2^{\text {rd }}$ service & 83.33 & 100 & 83.33 \\
\hline $3^{\text {Srd }}$ service & 100 & - & 100 \\
\hline No. of heifers to 3 months of preg. & 6 & 6 & 6 \\
\hline Pregnancy rate $(\%)^{*}$ & 100 & 100 & 100 \\
\hline Pregnancy rate $(\%)^{* *}$ & 100 & 100 & 100 \\
\hline No. of heifers embryonic loss & 0 & 0 & 0 \\
\hline Embryonic loss $(\%)^{* * * *}$ & 0 & 0 & 0 \\
\hline
\end{tabular}




\section{Farag et al.}

\section{REFERENCES}

Abdel- Salam, O. (2003). Response of Ossimi lambs fed high-energy concentrate feed mixture. Al-Azhar J. of Agric. Research. Vol. 37.

Abu El-Hamd, M. A. ; A. F. Mehrez; E. E. Rehrez and Sh. A. Gaber (2006). Productive and reproductive efficiencies of buffalo heifers under different feeding system . J. Agric. Res. Tanta Univ., 32 (1) : 1 22.

Ahamed, B. M.; H. T. Taie; M. M. Bendary and K. F. Abdel-Latif (2003). Influence of dietary corn silage on digestibility, performance and economical efficiency of dairy cattle. Egyptian J. Nutrition and Feeds, 6(Special Issue): 587.

Ali, M.A.E.; A.M. Abd El-Hafeez S.A. Ibrahim and Safaa N. Abd El-Azem (2014). The productive and reproductive efficiency of cow Baladi heifers under different levels of nutrition. Egyptian J. Nutrition and Feeds, 17(1): 51.

Almquist, J. O. and R. p. Amann (1976). Reproduction capacity of daily bulls Xl. Puberty characteristics and postpuberty changes in production of semen and sexual activity of Holstein bulls ejaculated frequently. J. Dairy Sci., 59: 986.

A.O.A.C. (1995). Official Methods of Analysis. 15th ed. Association of Official Analytical Chemists, Arlington, Virginiall USA.

Apgar, J. ; D. Aspros; J. E. Hixon; R. R. Saatman and W. Hansel (1975). Effect of restricted feed intake on the sensitivity of the bovine corpus luteum to LH in vitro. J. Anim. Sci., 41 : 1120.

Boland, M. P. (2002). A new frontier in trace mineral supplementation. Navigating from Niche Markets to Mainstream. Proceeding of Alltechs, European, Middle Eastern and African Lecture Tour.

Borghese, A. ; G. M. Terzano; V. L. Barile; A. Catalano and Malfatti (1996). Inter. Sym. on buffalo Resources and production system . Cairo, Egypt, Oct, 14-17 pp 41-46.

Borghese, A. ; V. L. Barile; G. Ficco; A. Galasso; E. Marchiori and G. M. Terzano (1997). Feeding system effect on reproduction performance in buffalo heifers. $5^{\text {th }}$ world Buffalo Cong. Proc. Caserta, Italy.

Choi, Y. J.; J. K. Han; J. H. Woo; H. J. Lee; k. Jang; K. H. Myung and Y. S. Kim (1997). Compensatory growth pattern on growth rate and lactation performance. J. dairy Sci. 80: 519.

Delavaud, C.; A. Ferlay, Y. Faulconnier, F. Bocquier, G. Kann, and Y. Chilliard. (2002). Plasma leptin concentration in adult cattle: Effects of breed, adiposity, feeding level, and meal intake. J. Anim. Sci. 80:1317.

D'-Hour, P; M. Petit and J. P.Garei (1996). Effect of nutrition level on development and puberty in Salers and Limousin heifers. 3emes rencontres autour des recherché sur les ruminants Paris. France, 4-5 December, 233.

Diskin, M.; V. Silke; J. F. Mee and J. M. Sreenan (2000). Embryo loss in dairy cows : implications for breeding management. Irish-Grasslan and Animal Production Assocition Journal., 34:34.

Doumas,B. ,W. Watson and H. Biggs. (1971). Albumin standars measurement of serum with bromocresol green. Clinical Chemistry Acta, 31:37.

Deutscher, G.H; L. L. Zerfoss and DC. Clanton (1986). Time of zeranol implantation on growth, reproduction and calving of beef heifers. J. of Animals Sci., 62: 4, 875.

Duncan (1955). Multiple range and multiple F test. Biometric, 11: 1-42.

El-Ashry, M. A. (1992). Impact of feeding on maturity and sexual performance of buffalo. Proce. Of the joint ESAP, EAAP, FAO, ICAMAS and OIE Symp., Cairo, EGYPT 9-12 Nov.

El-Ashry, M. A.; A. E.M. Khinizy; G. F. Shahin and M. E. Faarg (2007). Effect of two different concentrate levelsin the ration on meat productive from buffalo calves. Egyptian J. Nutrition and Feeds 10 (2)(Special Issue) 439.

El-Ashry, M. A.; G. F. Shahin ; T. I. El-Monayer and S. B. Mehany (2008). Effect of feeding different concentrate: corn silage ratio on body weight and age at conception of buffalo heifers. Egyptian $\mathrm{J}$. Nutrition and Feeds 11 (2)277. 
El-Banna, M.K; S.A. Ibrahim; H.M. Shabrawy and E.R. El-Sedfy (2004). Relationships among plan of nutrition, weight gain, age at puberty and reproductive performance in Baladi Heifers. J. Agric. Sci. Mansoura Univ., 29: 1091.

El-Feel, F. M. R.; A. K. I. Elmoty and A. A. Abd Elhakeam (1992). Puberty and post puberty changes in semen characteristics of buffalo and Friesian bull as affected by weaning system. Egyptian J. Aim. Prod. 29 (1): 1-15.

Etman , K. E. I; G. F. Shahin; A. A. El-Tahan and S. K. Sayed (2007). Studies on feeding allowances during different growth periods for crossed Friesian heifers. Egyptian J. Nutrition and Feeds 9 (2): 19.

Freetly, H. C. and L. V. Cundiff (1998). Reproductive performance, calf growth, and milk production of first calf heifers sired by seven breed and raised on different levels of nutrition.J. of Animal Sci., 76:6, 1513.

Foldager, J. and K. Sejrsen (1991). Rearing intensity in dairy heifers and the effect on subsequent milk production. In Danish with English summary and subtitles Report 693, Natl Inst Anim. Sci., Denmark.

Foldager, J. and K. L. Ingvartsen (1995). Production and health in first lactation in dairy cows in relation to prepartum ration energy concentration and energy level. Book of Abst. Of the $46^{\text {th }}$ Annual Meeting of EAAP. Prague, C Zech Republic, P. 88.

Grummar, R. R. ; P. C. Hoffman; M. L. Luck and S. J. Bertics (1995). Effect of prepartum and postpartum dietary energy on growth and lactation of primiparous cows. J. Dairy Sci., 78: 172.

Hall, J. B.; K. K. Schillo; B. P. Fitzgerald and N. W. Bradley (1994). Effect of recombinant somatotropin and dietary of intake on growth, secretion of luteinizing hormone, follicular development, and onset of puberty in beef heifers. J. Animal Sci., 72:3, 709.

Heinrichs, A. J. and G.L. Hargrove (1994). Standards of weight and heifer for Ayrshire, brown Swiss, and milking Shorthorn heifers. J. Dairy Sci., 77: 1676.

Heinrichs, A. J. and G.L. Hargrove (1987). Standards of weight and hight for Holstein heifers. J. Dairy Sci., 70: 653.

Henry R. J. (1964). Clinical chemistry Harber and Row publishers, New york p.181.

Ibrahim, S.; A.M. El-Gaafarawy; S.M. El-Sheikh; Hanaa, A. El-Koussy and S.A. Swiefy (2005). Feeding and meat production-related parameters in Baladi, Abondancex Baladi and Tarentaise $\times$ Baladi fattened calves. Proc. 2nd Conf. Anim. Prod. Res. Inst., Sakha 27-29 Sep.: 107.

Imakawa, K.; R. J. Kittok and J. E. Kinder (1983). Influence of dietary energy intake on progesterone, luteinizing hormone and estrous behavior in dairy heifers. J. Anim. Sci., 66: 90.

Kearl, L. C. (1982). Nutrients allowance of ruminants in developing countries. International Feedstuffs Institute Utah Agricultural Experiment Station Utah State University, Logan Utah December.

Knight, C. H., and C. J. Wilde (1994). Mammary cell changes during pregnancy and lactation. Livest. Prod. Sci. 35:3.

Mantysaari, P.; K. L. Ingvartsen; V. Toivanen and K. Sejrsen (1995). The effect of feeding level and nitrogen source of the diet on mammary development and plasma hormone concentration of prepubertal heifers. Acta. Agric. Scand. , Sect. A. Anim. Sci. 45: 236.

Mantysaari, P.; K. L. Ingvartsen and V. Toivanen ( 1999). Feeding intensity of pregnant heifers. Effect of feeding intensity during gestation on performance and plasma parameters of primiparous Ayrshiye cows. Livest. Prod. Sci., 62: 29.

Mantysaari, P. (2001). Effect of feeding before puberty and during gestation on milk production potential and body development of dairy replacement heifers. Univ. of Helsinki, Anim. Sci. Pub. Anim. Nutr. Acad. Disset.60.

McDonald, P.; R. A. Edward and J. F. D. Greenbolgh (1995). Animal nutrition (5 ${ }^{\text {th }}$ edition). Oliver and Boyd publisher.

Moran, C., J. F. Quirke, and J. F. Roche (1989). Puberty in heifers: A review. Anim. Reprod. Sci. 18:167.

Mosaad G.M. and D.R. Derar (2009). Effect of dietary energy and phosphorus on nutrients digestibility, blood constituents, and ovarian structures in ewes. Veterinary World, 2(12): 456. 


\section{Farag et al.}

Niekerk, A. van; R. Kernick; A. W. Lishman and A. Van-Niekerk (1990). The effect of winter and summer nutritional levels on the reproductive performance of beef heifers bred at 2 years of age. Animal Production, 51:2, 255.

Park, C. S., Y. J. Choi, L. K. Keller and R. L. Harrold (1988). Effect of compensatory growth on milk protein gene expression and mammary differentiation. FASEB J. 2, 2619.

Park, C. S., M. G. Baik, W. L. Keller, I. E. Berg and G. M. Erickson (1989). Role of compensatory growth in lactation A stair-step nutrient regimen modulates differentiation and lactation of bovine mammary gland. Growth Dev. Aging 58, 159.

Peri, I.; A. Gertler; I. Bruckental; and H. Barash (1993). The effect of manipulation of energy allowance during the rearing period of heifers on hormone concentrations and milk production in first lactation cows. J. Dairy Sci., 76: 742.

Prasad, D.; M. S. Saini; A. S. Virk; B. P. Sangupta and P. C. Gupta (1995). Optimum energy, protein and phosphorus requirements of breedable Murrah buffalo heifers. Buffalo Bulletin , 14:2,45.

Patton C. J. and S. R. Crouch (1977). Anal. Chem., 49: 464.

Purup, s.; K. Sejrsen; S. ; J. Foldager and R. M. Akers (1993). Effect of exogenous bovine growth hormone and ovariectomy on prepuberty mammary growth, serum hormone and in-vitro proliferative response of mammary explants from Holstein heifers. J. Endocrinol; 139: 19.

Radcliff, R. P.; M. J. Vanderhaar; L. T. Chapin; T. E. Pilpean; D. K. Beede; E. P. Stanisiewski and H. A. Tueker (2000). Effect of diet and injection of bovino somatotropin on prepubertal growth and first lactation milk yield of Holstein cows. J. Dairy Sci., 83: 23.

Robinson, J. J. (1990). Nutrition in the reproduction of farm animals. Nutr. Res. Rev. 3:253.

SAS (1998). Statistical analysis system SAS user's Guide: Statistics. SAS institute Inc. editors, Cary,N

Schillo, K. K., J. B. Hall, and S. M. Hileman (1992). Effects of nutrition and season on the onset of puberty in the beefheifer. J. Anim.Sci. 70:3994.

Schrick, F.N.; J.C. Spitzer; T.C. Jenkins; D.M. Henricks and T.G. Althen (1990). Effect of dietary energy restriction on metabolic and endocrine responses during the estrous cycle of the suckled beef cow. J. Anim. Sci., 68:3313.

Sejrsen, K., J. T. Huber, H. A. Tucker, and R. M. Akers (1983) . Influence of plane of nutrition on mammary development in pre- and postpubertal heifers. J. Dairy Sci. 65:783.

Sejrsen, K., S. ; J. Foldager ; M. T. Sqrensen; R. M. Akers and D. E. Bauman (1986). Effect of exogenous bovine somatotropin on puberty mammary development in heifers. J. Dairy sci., 69: 1528.

Sejrsen, K., and S. Purup (1997). Influence of prepubertal feeding level on milk yield potential of dairy heifers: A review. J. Anim. Sci. 75:828.

Sejrsen, K., S. Purup, H. Martinussen, and M. Vestergaard (1998).Effect of feeding level on mammary growth in calves and prepubertal heifers. J. Anim. Sci. suppl. 1. 76: 377.

Sejrsen, K., S. Purup, M. Vestergaard and J. Foldager (2000). High body weight gain and reduced bovine mammary growth : physiological basis and implications for milk yield potential. Domestic Animal Endocrinology, 19 :93.

Shahin, G. F.;M. A. Abd EL-latif; Mona E. Farag and S. A. Ebrahim (2016). Effect of feeding level regimes on: 1- Digestibility and performance of growing buffalo heifers. Under Publishing in Egyptian J. Nutrition and Feeds.

Shahin, G. F.; A. A. Mahrous; M. A. Abdel-Latif and A. A. El-Giziry (2012). Effect of feeding corn stover silage on growth and production performance of buffalo heifers. Egyptian J. Nutrition and Feeds 15 (1) Special Issue: 17-27.

Shahin, G. F. (2007). Response of pregnant Egyptian Crossbred Friesian heifers to feeding whole maize silage rations with different levels of feed intake. Egyptian J. Nutrition and Feeds 10 (2) Special Issue: 461.

Shahin, G. F. (2004). Effect of dietary energy level on nutrient utilization, productive and reproductive performance of growing buffalo heifers. Egyptian J. Nutrition and Feeds 7 (2): 143. 
Shahin, G. F.; A. A. Zaki and H. M. Yousf (2004). Effect of feeding level on growth, nutrient digestibility and feed efficiency for buffalo calves. Egyptian J. Nutrition and Feeds 7 (1): 11-12.

Shahin, G. F. (2000). Effect of dietary energy level and protein scours on sheep performance. Ph. D. Thesis, Fac. Agric. Menoufiya Univ.

Silke, V.; M. G. Dishin; D. A. Kenny; M. P. Boland; P. Dillon; J. F. Mee and J. M. Sreenan (2002). Extent, pattern and factors associated with late embryonic loss in dairy cows. Animal Reproduction Sci., 71: 1-2,1.

Steingass, H.; A. Haas; R. Stetter; T. Jilg and A. Susenbeth (1994). Influence of feeding level on nutrient and energy digestibility in sheep and cattle. Wirtschaftseigene-Futter. $40: 2-3,215$.

Stelwagen, K. and D. G. Grieve (1990). Effect of plane of nutrition on growth and mammary gland development in Holstein heifers. J. Dairy Sci., 73:2333.

Whitaker, D. A.; E. J. Smith; G. O. Rosa; J. M. Kelly and GO. Da Rosa (1993). Some effects of nutrition and management on the fertility of dairy cattle. Veterinary Record. 133:3, 61 . 
تأثير أنظمة مستوى التظذية على : 2- الأداء الإنتاجي والتناسلي لعجلات الجاموس النامي

منى أحمد السيد فرج" ، مجدي عبد الرحمن عيد اللطيف2 ، صلاح السيد عطية22 و عبد الفضيل عبد الحفيظ جبر2

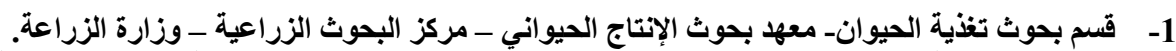

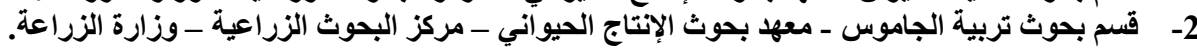

تهدف هذه الدراسة معرفة نأثير استخدام ثلاثة مستويات غذائية مختلفة لعجلات الجاموس النامي حسب مقررات كيرل 1982 من

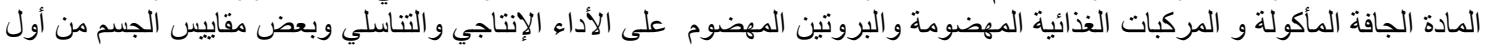

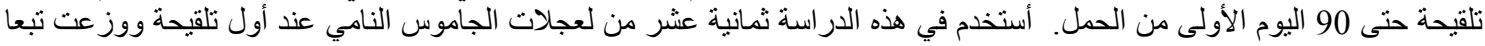

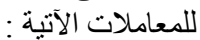

المعاملة الأولى : فيها تناولت العجلات غذاء يحتوى على 100\% من الاحتياجات الغذائية حسب مقررات كيرل 1982 واستمرت

حتى نهاية التجربة (كنترول).

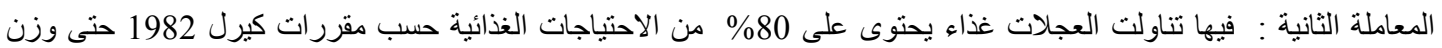

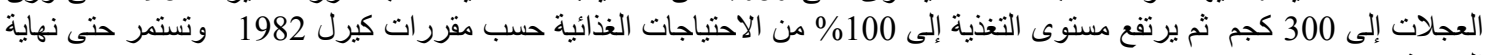

التجربة.

المعاملة الثالثة : فيها تناولت العجلات غذاء يحتوى على 80\% من من الاحتياجات الغذائية حسب مقررات كيرل 1982 واستمرت حتى الألى

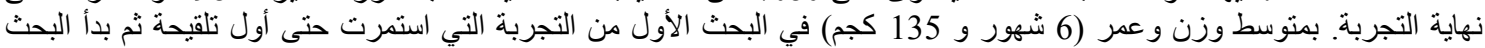

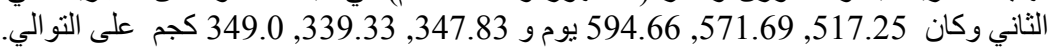

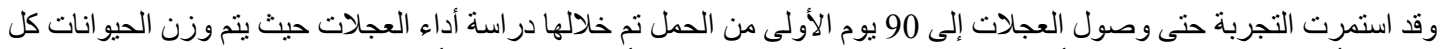

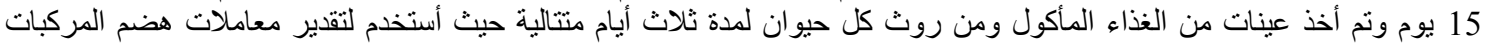
الغذائية المختلفة باستخدام الرماد غير الذائب كمرقم داخلي. وكانت أهم النتائج:

سجلت مجموعة الحيوانات التي غذيت على غذاء يحتوى على 80\% من الاحتياجات الغذائية حسب مقررات كيرل 1982 (المعاملة

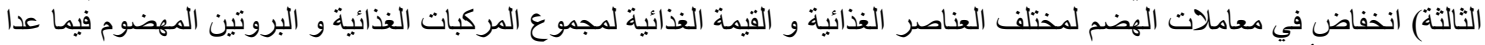

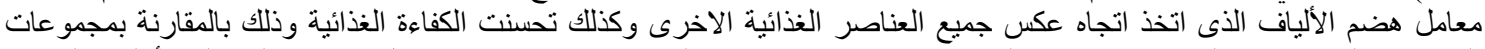

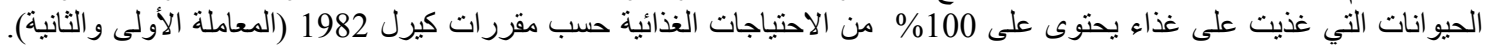

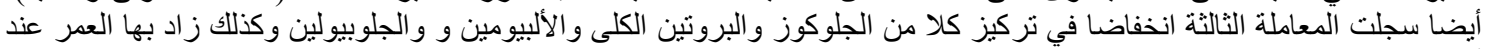

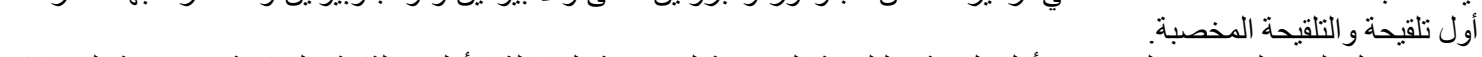
تحسن معدل النمو اليومي و العمر عند أول تلقيحة والتلقيحة المخصبة لمجموعة المعاملة الأولى والثانية بالمقارنة بمجموعة الحيوانات المعاملة الثالثة.

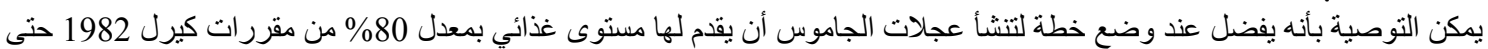

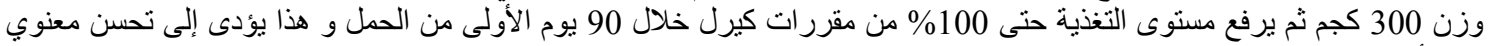
في الأداء الإنتاجي و التناسلي للعجلات. 